\title{
Performance of BARI ghom-26 Under Saline Stressed Condition
}

\author{
M. A. A. Al-Musa ${ }^{1}$, M. S. Islam², M. M. Moniruzzaman' ${ }^{2}$, M. S. Islam and S. Nasrin ${ }^{3}$ \\ ${ }^{1}$ FMO, IFDC Bangladesh, ${ }^{2}$ SAU, Dhaka; ${ }^{3}$ Res. Officer, (Agric), Bangladesh Water Dev. Board
}

\begin{abstract}
A pot experiment was carried out to study the performance of BARI ghom-26 under saline stressed condition in order to find out the optimum salinity level for cultivation. The study was consists of three salinity stressed levels viz. 4.0, 8.0 and 12.0 $\mathrm{dS} \mathrm{m} \mathrm{m}^{-1}$ together with a control $0.0 \mathrm{dSm}^{-1}$ for the observing the field performance under saline stressed condition of Patuakhali while salinity was applied in 45 Days After Sowing (DAS). This study also revealed plant height, leaf area index, stem dry weight pant $^{-1}$, shoot dry weight pant ${ }^{-1}$, root dry weight pant ${ }^{-1}$, total dry matter pant ${ }^{-1}$, number of effective tillers hill ${ }^{-1}$, length of spike $(\mathrm{cm})$, number of grain spike ${ }^{-1}, 1000$ grain weight $(\mathrm{g})$, grain yield plant ${ }^{-1}$, shoot yield plant ${ }^{-1}$, yield ha ${ }^{-1}$, harvest index and grain nutrient percentage were gradually decreased with continuing increased in salinity levels. Grain Na percentage reveled the antagonistic salinity effect on N P K absorbance. On the other hand, $4.0 \mathrm{dSm}^{-1}$ salinity found to be the considerable tolerance level for cultivating the BARI ghom-26 under saline stressed condition of Patuakhali.
\end{abstract}

Key words: BARI ghom-26 (wheat), salinity stressed, non-saline ecosystem

\section{Introduction}

Wheat (Triticum astivum L.) is one of the most important cereal crops of the world ranking first both in acreage and production among the puffed rice crops. Wheat is the second largest grain cereal crop next to rice in Bangladesh. Increasing population together with food shortages and land insufficiency are enforcing the nation to grow food crops on the land that has been unutilized because of soil problems. The area under wheat cultivation during 2007-2008 was about 923 thousand acres producing 31975 thousand M. tons of wheat with an average yield of $976 \mathrm{~kg}$ acre $^{-1}$ (BBS, 2010). It supplies carbohydrate, protein, minerals and vitamin (BARI, 1997) and preferable to rice for its higher seed protein content. Wheat seed contains $12 \%$ protein, $1.72 \%$ fat, $69.60 \%$ carbohydrates and $27.20 \%$ mineral matter. About $53 \%$ of $29,000 \mathrm{~km}^{2}$ coastal areas are affected by different degree of salinity. More than one million hectares of the coastal areas have been seriously affected by salinity (Rahman, 2008), which is considered as one of the major problems of crop production in Bangladesh. Salinity is one of the most important environmental stresses which severely limits plant growth and productivity worldwide (Tester and Davenport, 2003). The problem is ever increasing because of irrational human acts causing secondary salinization and climatic change with consequent rise in sea level (Haque, 2006). Consequently, higher rates of capillary action from an increased rate of topsoil desiccation would accentuate the salinity problem. There is also evidence that the yield of wheat in saline area decreases with increasing salinity level. So, the salinity is the most important problem for the yield performance of wheat. From the above facts, the present study was to find out the considerable tolerance level of salinity for cultivating the BARI ghom-26 under saline stressed condition of Patuakhali.

\section{Materials and Methods}

A pot experiment was conducted at the net house of the Department of Agricultural Botany, Patuakhali Science and Technology University (PSTU), Patuakhali during the period from November 2010 to April 2011. The soil was collected from the field laboratory of the PSTU. The experiment was laid out in RCBD with three replications. The variety BARI ghom-26 was used as planting materials and three salinity stressed levels viz. 4.0, 8.0 and $12.0 \mathrm{dS} \mathrm{m}^{-1}$ together with a control $0.0 \mathrm{dSm}^{-1}$ were also used while salinity was applied in 45 DAS. The soil, fertilizer $\left(100,60,40\right.$ and $7.5 \mathrm{~kg} \mathrm{ha}^{-1}$ of $\mathrm{N}, \mathrm{P}, \mathrm{K}$ and $\mathrm{Zn}$ respectively in the form of Urea, TSP and MoP and $\mathrm{ZnSO}_{4}$ ) and cowdung were mixed before putting the soil into the pots. Each pot was filled with $18 \mathrm{~kg}$ of mixture soil. After germination, healthy ten plants were selected for further study and four plants were collected from each pot for sampling and collecting the data on various morpho-physiologies at 100 DAS namely plant height in $\mathrm{cm}$; shoot, root and total dry matter weight in $\mathrm{g}$ plant $^{-1}$; LAI; and effective tillers hill $^{-1}$. Other plant were grown for collecting the data on yield and yield contributing characters at harvest such as 1000 grains weight in $\mathrm{g}$ at $12 \%$ moisture, grain and yield in $\mathrm{g} \mathrm{plant}^{-1}$ and harvest index in $\%$. Analysis of variance (ANOVA) and mean were done with the help of computer package M-STATC and mean differences among the varieties were adjusted with Duncan's Multiple Range Test (DMRT) at 5\% level of significance (Gomez and Gomez, 1984).

\section{Results and Discussion}

Plant height: Plant height is an important growth manifestation of plant. Saline condition might be reduced normal plant height which will be affecting 
on yield and yield contributing characters. For this observation, the tallest plant height was always found in control treatment. The control treatment found significantly $58.781 \mathrm{~cm}$ whereas $4.0 \mathrm{dSm}^{-1}$ gave the plant height of $43.633 \mathrm{~cm}$ which was comparable and ranked in second position. On the other hand, the shortest plant $(38.151 \mathrm{~cm})$ was also observed when the salinity level was $12.0 \mathrm{dS} \mathrm{m}^{-1}$ (Fig. 1). The different level of salinity varied on plant height. If the salinity dose increases plant height might be decreased in salinity stress due to the inhibition of cell

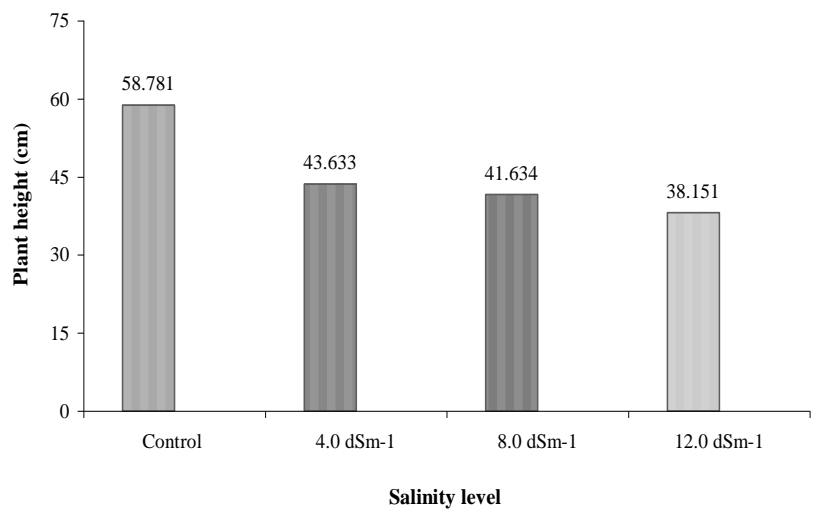

Fig. 1. Effect of salinity levels on plant height

Shoot dry weight (SDW): Effect of salinity stress on shoot dry weight was highly significant where the highest shoot dry weight (18.35 g plant $\left.{ }^{-1}\right)$ was observed in control followed by $4.0 \mathrm{dSm}^{-1}(15.30 \mathrm{~g})$ and the lowest shoot dry weight $\left(11.88 \mathrm{~g} \mathrm{plant}^{-1}\right)$ was taken in $12.0 \mathrm{dSm}^{-1}$ (Table 1). However the difference in the values of shoot dry weight decreased with the increasing level of salinity level. Decrease in shoot dry weight plant ${ }^{-1}$ under salinity stress might be because of inhibition of hydrolysis of reserve food or its translocation in the growing axis. Similar observation was also performed by Noaman (2000).

Root dry weight (RDW): Effect of salinity stress on root dry weight varied significant while salinity stress levels of $4.0 \mathrm{dSm}^{-1}$ showed root dry weight plant ${ }^{-1}$ of $1.24 \mathrm{~g}$ comparable with significant the highest $(1.70 \mathrm{~g})$ root dry weight plant ${ }^{-1}$ in control treatment. Among other salinity stress levels, $12.0 \mathrm{dSm}^{-1}$ constantly gave the significant lowest $(0.83 \mathrm{~g})$ root dry weight plant ${ }^{1}$ (Table 1). Root dry weight plant $^{-1}$ was also significantly decreased with the increased salinity levels in comparable to that of control treatment at every data recording stage. It is evident that root growth showed sensitivity to soil salinity. Similar results were also reported by Halim et al. (1988).

Total dry matter (TDM): TDM plant ${ }^{-1}$ due to salinity stress showed significant variance. The TDM of $16.548 \mathrm{~g}$ was observed when the salinity stress division or cell enlargement. Similar results are also found by Chhipa and Lal (1985) and Noaman (2000).

Leaf area index (LAI): The influence of salinity stress on leaf area showed significant dissimilarity at $5 \%$ level of significant. The highest LAI (1.63) was observed in control treatment $\left(\mathrm{T}_{0}\right)$ followed by 4.0 $\mathrm{dSm}^{-1}$ (1.32) while salinity stress level of $12.0 \mathrm{dSm}^{-1}$ showed the lowest LAI (0.89), because of leaf area index significantly decreased with the increase of salinity dose (Fig. 2).

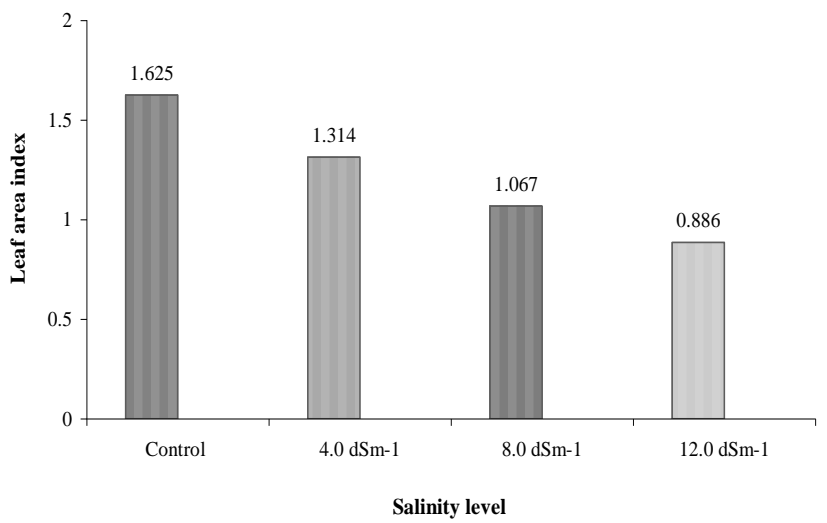

Fig. 2. Effect of different salinity levels on LAI

level was $4.0 \mathrm{dSm}^{-1}$ whereas no salinity showed the highest TDM (20.05 g). The lowest TDM (12.71 g) noticeably observed in $12.0 \mathrm{dSm}^{-1}$ (Table 1). These result revealed that the dissimilar salinity stress levels for TDM production showed decreased tendency with increasing level. In general, the TDM showed the superior result in no salinity condition might be due to increasing salinity stress levels injure cell enlarging system of any plant which effect on TDM and made up low TDM. However, the magnitude of reduction of TDM between control and the high levels (12.0 $\mathrm{dSm}^{-1}$ ) being greater difference at every stages. ElHendawy et al. (2009) agreed to the present study.

Effective tillers hill $^{-1}$ : Effective tillers hill ${ }^{-1}$ exerted significant difference where the maximum effective tillers hill $^{-1}$ (5.00) was recorded in without salinity followed by $4.0 \mathrm{dSm}^{1}$ (4.25) while it was minimum (3.792) in $12.0 \mathrm{dSm}^{1}$ salinity level (Fig. 3). This result revealed that the different level of salinity varied on number of effective tillers hill ${ }^{-1}$ in case of the plant cell division or cell enlargement system will be scratch with the increasing salinity. When the salinity level will very high and overcome the salinity stress tolerant level then plant will die. From these results it was evident that the different degree of salinity tolerance for number of effective tillers hill ${ }^{-1}$. The result at the present study is similar to the findings of Chhipa and Lal (1985) who found that the effective tillers in wheat was significantly reduced by increasing salinity level. 


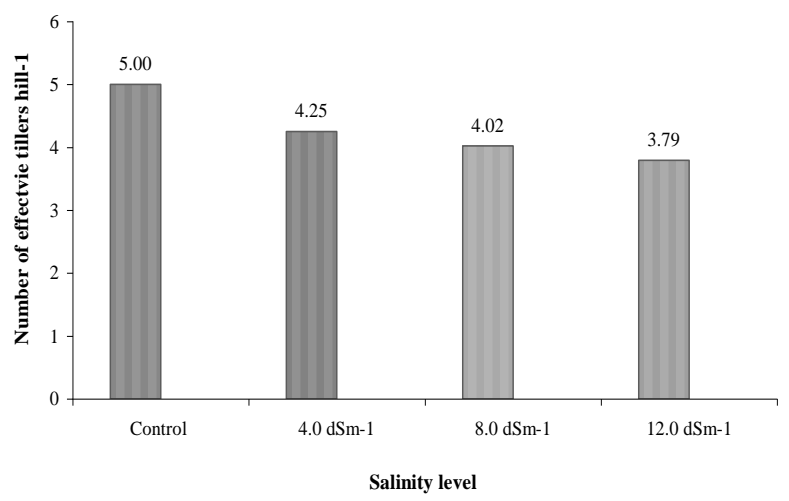

Fig. 3. Main effect of different salinity levels on number of effective tillers hill ${ }^{-1}$

Length of spike: Length of spike among the salinity stress level showed significant variation at $1 \%$ level of provability. The length of spike due to salinity stress level was found in the Table 2 where the longest spike $(17.30 \mathrm{~cm})$ was found in without salinity followed by $4.0 \mathrm{dSm}^{-1}(15.53 \mathrm{~cm})$ and the shortest $(13.182 \mathrm{~cm})$ was observed in $12.0 \mathrm{dSm}^{-1}$ salinity level (Table 1). The result showed that the increasing level of salinity stress decreasing the length of spike. Similar results were also trend by Halim et al. (1988) who reported that increased salinity stress decreased the length of spike.

Grains spike ${ }^{-1}$ : A significant variation was also found due to salinity stressed level regarding grain spike ${ }^{-1}$. Number of grain spike ${ }^{-1}$ of $41.79,40.21,35.13$ and 30.79 were observed in control treatment, $4.0 \mathrm{dSm}^{-1}$, $8.0 \mathrm{dS} \mathrm{m}^{-1}$ and $12.0 \mathrm{dSm}^{-1}$, respectively (Table 1). From the above results, it was clear that the number of grain spike ${ }^{-1}$ was decreased with the increase of salinity level. Salinity stress hinders the translocation ability of plant from vegetative organ to reproductive organ for these reasons less number of grains are developed in spike. Similar results were found by Halim et al. (1988) who reported that increased soil salinity decreased the number of grain spike ${ }^{-1}$.

Table 1. Effect of different treatments on morphological parameters

\begin{tabular}{|c|c|c|c|c|c|}
\hline $\begin{array}{c}\text { Salinity stressed } \\
\text { level }\left(\mathbf{d S m}^{-1}\right)\end{array}$ & $\begin{array}{c}\text { SDW } \\
\left(\text { g plant }^{-1}\right)\end{array}$ & $\begin{array}{c}\text { RDW } \\
\left(\text { g plant }^{-1}\right)\end{array}$ & $\begin{array}{c}\text { TDM } \\
\left(\text { g plant }^{-1}\right)\end{array}$ & $\begin{array}{l}\text { Length of } \\
\text { spike }(\mathrm{cm})\end{array}$ & $\begin{array}{c}\text { No. of grains } \\
\text { spike }^{-1}\end{array}$ \\
\hline 0 (Control) & $18.35 \mathrm{a}$ & $1.70 \mathrm{a}$ & $20.052 \mathrm{a}$ & $17.30 \mathrm{a}$ & $41.79 \mathrm{a}$ \\
\hline 4.0 & $15.30 \mathrm{~b}$ & $1.24 \mathrm{~b}$ & $16.548 \mathrm{~b}$ & $15.53 \mathrm{~b}$ & $40.21 \mathrm{~b}$ \\
\hline 8.0 & $13.60 \mathrm{c}$ & $1.12 \mathrm{c}$ & $14.722 \mathrm{c}$ & $14.31 \mathrm{c}$ & $35.13 \mathrm{c}$ \\
\hline 12.0 & $11.88 \mathrm{~d}$ & $0.83 \mathrm{~d}$ & $12.714 \mathrm{~d}$ & $13.18 \mathrm{~d}$ & $30.79 \mathrm{~d}$ \\
\hline CV (\%) & 0.27 & 0.25 & 0.24 & 0.09 & 0.47 \\
\hline
\end{tabular}

Thousand-grain weight: Significant variation $(\mathrm{P}<0.01)$ was also found on 1000-grain weight among the salinity stressed level. Without salinity level produced significantly the highest weight of 1000-grain $(49.51 \mathrm{~g})$ followed by $4.0 \mathrm{dSm}^{-1}(44.00 \mathrm{~g})$ and the lowest weight of 1000-grain (44.11 g) was observed in $12.0 \mathrm{dSm}^{-1}$ (Table 2). From the above result, it was comprehensible that the different salinity stressed level showed the variation regarding seed growth and size. Haqqani et al. (1984) reported that 1000-grain weight reduced with increased soil salinity stress.

Grain yield: Effect of salinity exerted significant in respect of grain yield. Among the salinity stressed level, grain yield had highest $\left(8.290 \mathrm{~g} \mathrm{plant}^{-1}\right.$ or $3.64 \mathrm{t}$ $\left.\mathrm{ha}^{-1}\right)$ in control followed by the second highest $(7.24 \mathrm{~g}$ plant $^{-1}$ or $3.18 \mathrm{t} \mathrm{ha}^{-1}$ ) in $4.0 \mathrm{dSm}^{-1}$ salinity level. Significantly the lowest grain yield $\left(5.44 \mathrm{~g} \mathrm{plant}^{-1}\right.$ or $2.39 \mathrm{t} \mathrm{ha}^{-1}$ ) was observed in $12.0 \mathrm{dSm}^{-1}$ salinity level (Table 2). Padole et al. (1995) observed that the yield of wheat was decreased at high saline soil. The present result was fully supportive with that finding. Salinity stress adversely affects the grain yield per plant. Due to salinity stress plant produced less number of tillers, less number of spikes and less assimilate through photosynthesis. As a result plants bear less number of spikes which contributes fewer yields.

Shoot yield: Shoot yield showed significant variation due to the salinity stressed level. Significantly the highest shoot yield (10.057 $\left.\mathrm{g} \mathrm{plant}^{-1}\right)$ was observed in control treatment followed by the second highest $\left(8.063 \mathrm{~g} \mathrm{plant}^{-1}\right)$ was also found in $4.0 \mathrm{dSm}^{-1}$ salinity level while significantly the lowest shoot yield $(6.438 \mathrm{~g}$ plant $^{-1}$ ) was found in $12.0 \mathrm{dSm}^{-1}$ salinity level. Increasing salinity stressed level gradually decreased the shoot yield which result was agreed to the findings of Chhipa and Lal (1985).

Harvest index (HI): Effect of different level of salinity on harvest index was significant where the highest $\mathrm{HI}(43.719 \%)$ was observed in $4.0 \mathrm{dSm}^{-1}$ salinity level and the lowest HI (41.313\%) was found in control treatment (Table 2). The result revealed that the harvest index decreased with the increasing salinity level might be due to the less effect reproductive growth (viz. grain growth, reserved translocation) than vegetative growth. 
Table 2. Effect of different treatments on botanical and yield contributing characters

\begin{tabular}{|c|c|c|c|c|c|}
\hline $\begin{array}{l}\text { Salinity stressed } \\
\text { level }\left(\mathrm{dSm}^{-1}\right)\end{array}$ & $\begin{array}{l}\text { 1000-grain } \\
\text { weight (g) }\end{array}$ & $\begin{array}{c}\text { Grain yield } \\
\left(\text { g plant }^{-1}\right)\end{array}$ & $\begin{array}{l}\text { Grain yield } \\
\left(\mathrm{t} \mathrm{ha}^{-1}\right)\end{array}$ & $\begin{array}{c}\text { Shoot yield } \\
\left(\text { g plant }^{-1}\right)\end{array}$ & $\begin{array}{c}\text { Harvest index } \\
(\%)\end{array}$ \\
\hline 0 (Control) & $49.51 \mathrm{a}$ & $8.290 \mathrm{a}$ & 3.029 & $10.057 \mathrm{a}$ & $41.313 \mathrm{~d}$ \\
\hline 4.0 & $45.00 \mathrm{~b}$ & $7.242 \mathrm{~b}$ & 2.726 & $8.063 \mathrm{~b}$ & $43.719 \mathrm{a}$ \\
\hline 8.0 & $45.08 \mathrm{c}$ & $6.342 \mathrm{c}$ & 2.899 & $7.259 \mathrm{c}$ & $43.034 b$ \\
\hline 12.0 & $44.11 \mathrm{~d}$ & $5.442 \mathrm{~d}$ & 3.353 & $6.438 \mathrm{~d}$ & $42.777 \mathrm{c}$ \\
\hline $\mathrm{CV}(\%)$ & 0.55 & 0.22 & 0.22 & 0.51 & 0.32 \\
\hline
\end{tabular}

\section{REFERENCES}

BARI (Bangladesh Agricultural Research Institute) 1997. Increase wheat cultivation and decrease irrigation cost (A folder in Bengali) Wheat Res. Centre. Bangladesh Agril. Res. Inst. Nashipur, Dinajpur. pp. 12-15.

BBS (Bangladesh Bureau of Statistics) 2010. Statistical Year Book of Bangladesh. BBS Div. Min. Plan., Govt. Peoples Repub. Bangladesh, p. 144.

Chhipa, B.P. and Lal, P. 1985. Effect of soil salinity on yield, yield attributes and nutrient uptake by different varieties of wheat. Annales de Edafologia Y Agrobiol. 44(11/12): 1681-1691.

El-Hendawy, S.E.; Ruan, Y.; Hu, Y. and Schmidhalter, U. 2009. A comparison of screening criteria for salt tolerance in wheat under field and controlled environmental conditions. J. Agron Crop Sci., 195: 356-367

Gomez, K.A. and Gomez, A.A. 1984. Statistical Procedures for Agricultural Research. $2^{\text {nd }} \mathrm{Edn}$. John Willey and Sons, New York. pp. 97-411.
Halim, A.; Salih, R.K.; Ahmed, H.M. and Rahim, A.A. 1988. Growth and development of Maxipak wheat as affected by soil salinity and moisture levels. Plant Soil., 11(2): 225-229.

Haqqani, A.M.; Rant, A. and Zahid, M.A. 1984. Salt tolerance physiol., 31: 14-190.

Haque, S.A. 2006. Salinity problems and crop production in coastal regions of Bangladesh. Pak. J. Bot., 38(5): 1359-1365.

Noaman, M.M. 2000. Evaluation of some, recombinant line of Triticum lurgidum L. for salt tolerance. J. Arid. Environ., 46(3): 239-247.

Padole, V.Z.; Bhalkar, D.V. and Kale, V.B. 1995. Effect of quality of irrigation water on wheat grown under conditions of salinity sodicity. PKV Res., 19(1): 34-38.

Rahman, M.; Soomro, U.A.; Haq, M.Z. and Gul, S. 2008. Effects of $\mathrm{NaCl}$ salinity on wheat (Triticum aestivum L.) cultivars. W. J. Agril. Sci., 4(3): 398-403.

Tester, M. and Davenport, R. 2003. Na+ tolerance and $\mathrm{Na}+$ transport in higher plants. Ann. Bot., 91: 503-527. 